\title{
Optimalisasi Peran Guru Pendidikan Agama Islam sebagai Konselor dalam Mengatasi Masalah Belajar Siswa
}

\author{
Asep Nanang Yuhana \\ Institut Agama Islam Darussalam (IAID) Ciamis, Jawa Barat. \\ Email: asepny1995@yahoo.co.id \\ Fadlilah Aisah Aminy \\ Fakultas Tarbiyah, Institut Agama Islam Darussalam (IAID) Ciamis, Jawa Barat. \\ Email: fadlilah_aminy@yahoo.co.id
}

Received: October 4, 2018 | Accepted: April 7, 2019

\begin{abstract}
This article aims to look for learning problems faced by students of class VI MIS Handapherang-Ciamis, the teacher's efforts and the steps taken to overcome these problems. By using qualitative-descriptive method, research concludes; First, students experience difficulty in reading and writing. The problem factor comes from the parents and from the students themselves. Second, the efforts made by the class teacher at school to grade VI students who experience learning problems that is maximizing their sense of hearing by listening to the teacher when explaining the learning material, guided when the child does not understand the learning material and finally teacher guided when the child does not pay attention to the teacher explaining in learning process. Third, the teacher's stages in overcoming student learning problems starts from determining the problem to solving the problems that occur in students of class VI MIS Handapherang.
\end{abstract}

\begin{abstract}
Abstrak
Artikel ini bertujuan untuk mencari masalah belajar yang dihadapi siswa kelas VI MIS Handapherang-Ciamis, upaya guru dan tahapan-tahapan yang ditempuh dalam mengatasi permasalahan tersebut. Dengan menggunakan metode kualitatif-deskriptif, penelitian mengahsilkan kesimpulan; Pertama, siswa mengalami kesulitan dalam membaca dan menulis. Faktor masalah yang terjadi berasal dari faktor orang tua dan dari diri siswanya sendiri. Kedua, Upaya yang dilakukan guru kelas di sekolah pada siswa kelas VI yang mengalami masalah belajar yaitu memaksimalkan indra pendengarannya dengan cara mendengarkan guru ketika menjelaskan materi pembelajaran, dibimbing ketika anak tidak mengerti dalam materi pembelajaran dan yang terakhir diarahkan ketika anak tidak memperhatikan guru menjelaskan materi dalam proses pembelajaran. Ketiga, tahapan guru dalam mengatasi masalah belajar siswa dimulai dari menentukan masalah sampai dengan penyelesaian masalah yang terjadi pada siswa kelas VI MIS Handapherang.
\end{abstract}




\section{Keywords}

Islamic education, teacher as counselor, student learning problems

\section{Pendahuluan}

Dalam UU Nomor 20 tahun 2003 pasal 4 ayat 4 tentang Sistem Pendidikan Nasional (SISDIKNAS) pendidikan diselenggarakan dengan memberi keteladanan, membangun kemauan, dan mengembangkan kreativitas peserta didik dalam proses pembelajaran. Belajar merupakan suatu usaha sadar manusia dalam mendidik dalam upaya meningkatkan kemampuan kemudian diiringi oleh perubahan dan peningkatan kualitas dan kuantitas pengetahuan manusia itu sendiri. Belajar adalah suatu aktivitas yang terjadi di dalam lingkungan belajar. Belajar diperoleh melalui lembaga pendidikan formal dan non formal. Salah satu pendidikan formal yang umum di Indonesia yaitu sekolah dimana di dalamnya terjadi kegiatan belajar dan mengajar yang melibatkan interaksi antara guru dan siswa. Tujuan belajar siswa sendiri adalah untuk mencapai atau memperoleh pengetahuan yang tercantum melalui hasil belajar yang optimal sesuai dengan kecerdasan intelektual yang dimilikinya (Djamarah, 2008, p. 10).

Sekolah atau lembaga pendidikan formal, pada umumnya sekurangkurangnya ada 3 ruang lingkup kegiatan kegiatan pendidikan, yaitu bidang intruksional dan kurikulum (pengajaran), bidang administrasi dan kepemimpinan, bidang pembinaan pribadi (Andi, 2002, pp. 11-12). Kegiatan pendidikan yang baik, hendaknya mencangkup ketiga bidang tersebut. Sekolah atau lembaga yang hanya menjalankan program kegiatan intruksional (pengajaran) dan administrasi saja, tanpa memperhatikan ketiga pembinaan pribadi siswa mungkin hanya akan menghasilkan individu yang pintar dan cakap serta bercita-cita tinggi tetapi mereka kurang memahami potensi yang dimilikinya dan kurang atau tidak mampu mewujudkan dirinya di dalam kehidupan masyarakat.

Sebagai seorang guru yang sehari-hari mengajar di sekolah, tentunya tidak jarang dalam menangani siswa yang mengalami kesulitan belajar. Banyak siswa yang sangat sulit sekali menerima mata pelajaran, baik pelajaran membaca, menulis serta berhitung. Hal ini terkadang membuat guru menjadi memikirkan bagaimana menghadapi siswa yang mengalami kesulitan belajar (Syah, 2002).

Permasalahan yang dialami para peserta didik disekolah sering kali tidak dapat dihindari meski dengan pengajaran yang baik sekalipun. Hal ini terlebih 
lagi disebabkan karena sumber-sumber permasalahan peserta didik banyak yang terletak diluar sekolah. Layanan bimbingan dan konseling yang diberikan di sekolah dasar mencakup komponen bimbingan pribadi, sosial, belajar dan karier. Layanan bimbingan pribadi bertujuan membantu peserta didik menemukan dan memahami serta mengembangkan pribadi yang beriman dan bertakwa kepada Tuhan Yang Maha Esa, mandiri, aktif, kreatif, serta sehat secara jasmani dan rohani.

Dalam bidang belajar, bimbingan berupa membantu peserta didik mengembangkan kebiasaan belajar yang baik dalam menguasai pengetahuan, ketrampilan, serta menyiapkannya untuk melanjutkan studi. Hal ini karena kemandirian dalam belajar merupakan dasar bagi peserta didik mengembangkan setiap kompetisi yang dimilikinya. Bimbingan dan Konseling merupakan layanan bantuan kepada peserta didik, baik secara perorangan maupun kelompok, agar mampu mandiri dan berkembang secara optimal dalam bidang bimbingan pribadi, bimbingan sosial, bimbingan belajar dan bimbingan karir, melalui berbagai jenis layanan dan kegiatan pendukung, berdasarkan norma-norma yang berlaku (Prayitno \& Amti, 2004, pp. 10-11).

Secara umum tujuan dari layanan bimbingan dan konseling adalah sesuai dengan tujuan pendidikan nasional, sebagaimana tertuang dalam undangundang sistim Pendidikan Nasional No. 20 Tahun 2003, yaitu untuk mengembangkan potensi peserta didik agar menjadi manusia yang beriman dan bertakwa kepada Tuhan Yang Maha Esa, berakhlak mulia, sehat, berilmu, cakap kreatif, mandiri, dan menjadi warga negara yang demokratis serta bertanggung jawab, sedangkan tujuan kusus dari layanan bimbingan dan konseling adalah untuk membantu siswa agar dapat mencapai tujuan-tujuan perkembangan yang meliputi aspek pribadi, sosial, belajar, dan karir. Secara formal kedudukan bimbingan dan konseling dalam sistem pendidikan di Indonesia ada di dalam undang-undang No 20/2003 tentang sistem pendidikan nasional beserta perangkat peraturan pemerintahannya, sedangkan hal-hal yang berhubungan dengan pendidikan dasar dimana sekolah dasar ada didalamnya dibicarakan secara khusus dalam PP No, 28/1999 tentang pendidikan dasar bab X pada pasal 25 ayat I. Mengingat pentingnya bimbingan di sekolah maka dengan ini salah satunya adalah kegiatan belajar yang diberikan pada siswa agar bisa menjadi individu yang mampu berkompetensi. Kegiatan belajar yang dimaksud adalah untuk memberikan bantuan kepada siswa dalam memecahkan kesulitan kesulitan atau berhubungan dengan masalah belajar (Dahlan, 2017, p. 13).

Biasanya kemampuan siswa dalam belajar seringkali dikaitkan dengan kemampuan intelektualnya. Ada siswa dengan kecerdasan intelektual diatas rata-rata atau rata-rata tinggi namun tidak menunjukkan prestasi yang 
memuaskan yang sesuai dengan kemampuannya yang diharapkan dalam belajar. Kemudian ada siswa yang mendapatkan kesempatan yang baik dalam belajar, dengan kemampuan yang cukup baik, namun tidak menunjukkan prestasi yang cukup baik dalam belajar. Dan ada pula siswa yang sangat bersungguh-sungguh dalam belajar dengan kemampuan yang kurang dan prestasi belajarnya tetap saja kurang. Hal ini menunjukkan bahwa terdapat hambatan dan masalah dalam proses belajar siswa itu sendiri, baik dalam prosesnya di sekolah maupun dirumah. Oleh karena itu, guru selaku pendidik dituntut untuk selalu dapat memberikan dorongan atau motivasi kepada siswanya yang kurang bersemangat dalam belajar dan memberikan solusi terhadap permasalahan belajar yang dihadapi siswanya.

Secara umum belajar dapat diartikan sebagai proses perubahan prilaku yang diakibatkan oleh interaksi siswa dengan lingkungan. Perilaku ini mencangkup pengetahuan, pemahaman, keterampilan, sikap dan sebagainya. Sehingga kita dapat mengidentifikasi hasil belajar melalui penampilan. Sebagaimana yang dikatakan Kimble dan Garmezy dalam Moh. Ali, sifat perubahan prilaku belajar relative permanen (Ali, 2000, p. 14).

Masalah pengertian belajar ini, para ahli psikologi dan pendidikan mengemukakan rumusan yang berlainan sesuai dengan bidang keahlian mereka masing-masing. Tentu saja mereka mempunyai alasan yang dapat dipertanggung jawabkan secara ilmiah. Slameto merumuskan pengertian tantang belajar. Menurutnya belajar adalah suatu proses usaha yang dilakukan individu untuk memperoleh suatu perubahan tingkah laku yang baru secara keseluruhan, sebagai hasil pengalaman individu itu sendiri dalam interaksi dengan lingkungan. Dari pendapat para ahli tentang pengertian belajar yang dikemukakan di atas dapat dipahami bahwa belajar adalah suatu kegiatan yang dilakukan dengan melibatkan dua unsur, yaitu jiwa dan raga. Gerak raga yang di tunjukan harus sejalan dengan proses jiwa untuk mendapatkan perubahan. Tentu saja perubahan yang didapatkan itu bukan berupa fisik, tetapi perubahan jiwa dengan sebab masuknya kesan-kesan yang baru (Djamarah, 2008, pp. 12-13).

Secara psikologis, belajar merupakan suatu proses perubahan yaitu tingkah laku sebagai hasil dari interaksi dengan lingkungannya dalam memenuhi kebutuhan hidupnya. Perubahan-perubahan tersebut akan nyata seluruh aspek tingka laku. Pengertian belajar dapat didefinisikan sebagai berikut: "Belajar ialah suatu proses usaha yang dilakukan seseorang untuk memperoleh suatu perubahan tingkah laku yang baru secara keseluruhan, sebagai hasil pengalamannya sendiri dalam interkasi dengan lingkungan" (Slameto, 2015, p. 2). Perubahan yang terjadi dalam diri seseorang banyak sekali baik sifat maupun jenisnya karena itu sudah tentu tidak setiap perubahan 
dalam diri seseorang merupakan perubahan dalam arti belajar. Kalau tangan seorang anak bengkok karena patah, perubahan semacam itu tidak dapat digolongkan ke dalam perubahan dalam arti belajar. Demikian pula dengan tingkah laku sesorang yang berada dalam keadaan mabuk, perubahan yang terjadi dalam aspek-aspek kematangan, pertumbuhan, dan perkembangan tidak termasuk perubahan dalam pengetian belajar (Slameto, 2015, p. 2). Lebih lanjut Slameto menjelaskan bahwa perubahan dalam belajar memiliki sifat tersendiri.

Pertama, perubahan terjadi secara sadar. Seseorang yang belajar akan menyadari terjadinya perubahan itu atau sekurang-kurangnya ia merasakan telah terjadi adanya suatu perubahan dalam dirinya. Misalnya ia menyadari bahwa pengetahuannya bertambah, kecakapannya dan kebiasaannya bertambah.

Kedua, perubahan dalam belajar bersifat kontinu dan fungsional. Sebagian hasil belajar, perubahan yang terjadi dalam arti seseorang berlangsung secara berkesinambungan, tidak statis. Satu perubahan yang terjadi akan menybabkan perubahan berikutnya dan akan berguna lagi bagi kehidupan ataupun proses belajar berikutnya. Misalnya jika sesorang anak belajar menulis, maka ia akan mengalami perubahan dari tidak dapat menulis menjadi dapat menulis. Perubahan ini berlangsung terus hingga kecakapan menulisnya menjadi lebih baik dan sempurna; ketiga, perubahan dalam belajar bersifat positif dan aktif. Dalam perubahan belajar, perubahan-perubahan itu senantiasa bertambah dan tertuju untuk memperoleh suatu yang lebih baik dari sebelumnya. Dengan demikian makin banyak usaha belajar itu dilakukan, makin banyak dan makin baik perubahan yang diperoleh. Perubahan yang bersifat aktif artinya bahwa perubahan itu tidak terjadi dengan sendirinya melainkan karena usaha individu sendiri. Misalnya perubahan tingkah laku karena usaha orang yang bersangkutan.

Ketiga, perubahan dalam belajar bukan bersifat sementara. Perubahan yang bersifat sementara atau temporer terjadi hanya untuk beberapa saat saja, seperti berkeringat, keluar air mata, menangis dan sebagainya, tidak dapat digolongkan sebagai perubahan dalam arti belajar. Perubahan yang tejadi karena proses belajar besifat menetap atau permanen. Ini berarti bahwa tingkah laku yang terjadi setelah belajar akan bersifat menetap. Misalnya kecakapan seseorang anak dalam memaikan piano setelah belajar, tidak akan hilang begitu saja melainkan akan terus dimiliki bahkan akan makin berkembang kalau terus dipergunakan atau dilatih.

Keempat, perubahan dalam belajar bertujuan atau terarah. Perubahan tingkah laku itu terjadi karena ada tujuan yang akan dicapai. Perubahan belajar terarah kepada perubahan tingkah laku yang benar-benar disadari. Misalnya 
seseorang yang belajar mengetik, sebelumnya sudah menetapkan apa yang mungkin dapat dicapai dengan belajar mengetik, atau tingkah kecakapan mana yang akan dicapai. Dengan demikian perbuatan belajar yang dilakukan senantiasa terarah kepada tingkah laku yang telah ditetapkan.

Kelima, perubahan mencakup seluruh aspek tingkah laku. Perubahan yang diperoeh seseornag setelah memalui suatu proses belajar meliputi perubahan keseluruhan tingkah laku. Jika seseorang belajar sesuatu, sebagai hasilnya ia akan mengalami perubahan tingkah laku secara menyeluruh dalam sikap, keterampilan, pengetahuan, dan sebagainya (Slameto, 2015, pp. 3-4).

Piaget dalam (Slameto, 2015, pp. 12-13) berpendapat mengenai perkembangan proses belajar pada anak-anak sebagai berikut; 1) anak memepunyai stuktur mental yang berbeda dengan orang dewasa. Mereka bukan merupakan orang dewasa dalam bentuk kecil, mereka mempunyai cara yang khas untuk menyatkan kenyataan dan untuk menghayati dunia sekitarnya. Maka memerlukan pelayanan tersendiri dalam belajar; 2) perkembangan mental pada anak memalui tahapan-tahapan tertentu, menurut suatu urutan yang sama bagi semua anak; 3 ) walaupun berlangsungnya tahaptahap perkembangan itu melalui suatu urutan tertentu, tetapi jangka waktu berlatih dari satu tahap ke tahap yang lain tidaklah selalu sama pada setiap anak; 4) perkembangan mental anak di pengaruhi oleh 4 faktor, yaitu: a) kemasakan; b) pengalaman; c) interaksi sosial; d) equilibration (proses dari ketiga faktor diatas bersama-sama untuk membangun dan memperbaiki struktur mental).

R. Gagne dalam (Slameto, 2015, pp. 13-15) mengemukakan tentang masalah belajar, Gagne memberikan dua definisi, yaitu: pertama, belajar ialah suatu proses untuk memperoleh motivasi dalam pengetahuan, keterampilan, kebiasaan, dan tingkah laku; kedua, belajar adalah penguasaan pengetahuan atau keterampilan yang diperoleh dari instruksi. Mulai masa bayi manusia mengadakan interaksi dengan lingkungannya, tetapi baru dalam bentuk "sensori-motor coordination". Kemudian ia mulai belajar berbicara dengan menggunakan bahasa. Kesanggupan untuk menggunakan bahasa ini penting artinya untuk belajar. Tugas pertama yang dilakukan anak ialah meneruskan "sosialisasi" dengan anak lain. Atau orang dewasa, tanpa pertentangan bahkan untuk membantu memenuhi kebutuhan-kebutuhan keramahan dan konsiderasi pada anak itu. Tugas kedua ialah belajar menggunakan simbolsimbol yang menyatakan keadaan sekelilinnya, seperti gambar, huruf, angka, diagram dan sebagainya. Ini adalah tugas intelektual (membaca, menulis, berhitung dan sebagainya). Bila anak sekolah sudah dapat memalukan tugas ini, berarti di sudah mampu belajar banyak hal dari yang mudah sampai yang amat komplek. 
Lebih lanjut Gagne dalam (Slameto, 2015, p. 16) mengatakan pula bahwa segala hal sesuatu yang dipelajari oleh manusia dapat dibagi menjadi 5 kategori, yang disebut "the domain of learning" yaitu; 1) keterampilan motoris (motor sklill). Dalam hal ini perlu kordinasi dari berbagai gerakan badan, misalnya melempar bola, main tenis, menulis huruf dan sebagainya; 2) informasi verbal. Orang dapat mejelaskan sesuatu dengan berbicara, menulis, menggambar, dalam hal ini dapat dimengerti bahawa untuk mengatakan tidak perlu inteligensi; 3) kemampuan intelektual. Manusia mengadakan interaksi dengan dunia liar dengan menggunakan simbol-simbol. Kemampuan belajar cara inilah yang disebut "kemampuan intelektual" misalnya membedakan huruf $m$ dan $n$, menyebutkan tanaman yang sejenisnya; 4) strategi kognitif. Ini merupakan organisasi keterampilan yang internal (internal organisasational skill) yang perlu untuk belajar mengingat dan berpikit. Kemampuan ini berbeda dengan kemampuan intelektual, karena ditujukan ke dunia luar, dan tidak dapat dipelajari hanya dengan berbuat satu kali serta memerlukan perbaikanperbaikan secara terus menerus; 5) sikap. Kemampuan ini tidak dapat dipelajari dengan ulangan-ulangan, tidak tergantung atau dipengaruhi oleh hubugan verbal seperti halnya domain yang lain. Sikap ini penting dalam proses belajar, tanpa kemampuan ini belajar tak akan berhasil dengan baik.

Pendidikan dasar adalah bagian terpadu dari sistem pendidikan nasional yang berlangsung selama 6 tahun di sekolah dasar (SD) dan selama 3 tahun di sekolah lanjutan tingkat pertama (SLTP) atau satuan pendidikan yang sederajat. Pada umumnya kira-kira 6 tahun anak memasuki jenjang pendidikan formal. Kebutuhan pada anak sekolah, yang terutama berkisar pada kebutuhan mendapat kasih sayang dan perhatian, menerima pengakuan terhadap dorongan untuk memajukan perkembangan kognitifnya, serat memperoleh pengakuan dari teman sebaya. Tugas-tugas perkembangan yang dihadapi siswa adalah mengatur beraneka kegiatan belajar dengan bersikap tanggung jawab, bertingkah laku dengan cara yang dapat diterima oleh orang serta teman-teman sebayanya, cepat mengembangkan bekal kemampuan dasar dalam membaca, menulis dan berhitung (Winkel \& Hastuti, 2013, pp. 137-139).

Dalam suatu perkembangan anak di sekolah tidak semua perkembangan anak akan berjalan dengan sempurna pasti akan mengalami yang namanya masalah dalam belajar. Prayitno mengemukakan masalah belajar adalah sesuatu yang tidak disukai adanya, menimbulkan kesulitan bagi diri sendiri dan atau orang lain, ingin atau perlu dihilangkan. Dari definisi masalah dan belajar maka masalah belajar dapat diartikan atau didefinisikan sebagai berikut."Masalah belajar adalah suatu kondisi tertentu yang dialami oleh siswa dan menghambat kelancaran proses yang dilakukan individu untuk memperoleh suatu perubahan tingkah laku yang baru secara keseluruhan" 
atau masalah belajar adalah suatu kondisi tertentu yang dialami oleh siswa dan menghambat kelancaran proses belajar, bisa berkenaan dengan keadaan diri siswa itu sendiri ataupun berkenaan dengan lingkungan yang tidak menguntungkan (Prayitno \& Amti, 2004, p. 17).

Kondisi tertentu itu dapat berkenaan dengan keadaan dirinya yaitu berupa kelemahan-kelemahan dan dapat juga berkenaan dengan lingkungan yang tidak menguntungkan bagi dirinya. Masalah-masalah belajar ini tidak hanya dialami oleh siswa-siswa yang lambat saja dalam belajarnya, tetapi juga dapat menimpa siswa-siswa yang memiliki kemampuan diatas rata-rata normal, pandai atau cerdas (Dimyati \& Mudjiono, 2013, p. 12).

Secara etimologis, bimbingan dan konseling terdiri atas dua kata yaitu "bimbingan" (guidance) dan "konseling" (counseling). Dalam praktik, bimbingan dan konseling merupakan satu kesatuan kegiatan yang tidak terpisahkan. Keduanya merupakan bagian yang integral (Tohirin, 2007, p. 15). Manusia pada hakikatnya diciptakan dalam keadaan yang terbaik, termulia, tersempurna, dibandingkan makhluk lainnya, tetapi sekaligus memiliki hawa nafsu dan perangai atau sifat tabiat buruk, misalnya suka menuruti hawa nafsu, membantah dan lain-lain, karena manusia dapat terjerumus ke dalam lembah kenistaan, kesengsaraan, dan kehinaan. Dengan kata lain, manusia bisa bahagia hidupnya di dunia maupun akhirat, dan bisa pula sengsara atau tersiksa.

Bimbingan merupakan terjemahan dari kata guidance dikaitkan dengan kata asal guide, yang diartikan sebagai berikut: menunjukan jalan (showing the way); memimpin (leading); menuntun (conducting); memberikan petunjuk (giving instruction); mengatur (regulating); mengarahkan (govergiving); memberikan nasehat (giving advice). Istilah bimbingan dalam bahasa Indonesia diberi arti yang selaras denagn arti-arti yang disebutkan di atas, akan muncul dua pengertian yang agak mendasar, yaitu; 1) memberikan informasi, yaitu menyajikan pengetahuan yang dapat digunakan untuk mengambil suatu keputusan, atau memberikan sesuatu sambil memberikan nasihat; 2) mengarahkan, menuntut ke suatu tujuan. Tujuan itu mungkin hanya diketahui oleh pihak yang mengarahkan, mungkin perlu diketahui oleh dua pihak (Winkel \& Hastuti, 2013, p. 27).

Istilah guidance, diterjemahkan dengan arti bantuan atau tuntunan. Ada juga yang menerjemahkan kata guidance dengan arti pertolongan. Berdasarkan arti ini, secara etimologi, bimbingan berarti bantuan atau tuntunan, pertolongan; tetapi tidak semua bantuan, tuntunan atau pertolongan berarti konteksnya bimbingan. Seorang guru yang membantu siswanya menjawab soal-soal ujian bukan merupakan suatu bentuk bimbingan. Bantuan, tuntunan, atau pertolongan yang bermakna bimbingan konteksnya sangat psikologis. Selain itu bantuan, tuntunan atau pertolongan yang bermakna bimbingan 
harus memenuhi syarat-syarat sebagai berikut; a) ada tujuan yang jelas untuk apa bantuan itu diberikan; b) harus terencana (tidak asal-asalan); c) berperoses dan sistematis (melalui tahapan-tahapan tertentu); d) menggunakan cara atau pendekatan tertentu; e) dilakukan oleh orang ahli (memiliki pengetahuan bimbingan); f) dievaluasi untuk mengetahui hasil dari pemberian bantuan, tuntunan, pertolongan.

Miller (1996) dalam (Suryana \& Suryadi, 2012, p. 17) menyatakan bahwa bimbingan merupakan proses bantuan terhadap individu untuk mencapai pemahaman diri dan pengarahan diri yang dibutuhkan untuk melakukan penyesuaian diri secara maksimal kepada sekolah, keluarga, masyarakat. Konseling (counseling) merupakan bagian integral dari bimbingan. Konseling juga merupakan salah satu teknik dalam bimbingan. Konseling merupakan inti dari bimbingan. Ada yang menyatakan bahwa konseling merupakan "jantungnya" bimbingan. Sebagai kegiatan inti atau jantungnya bimbingan, praktik bimbingan bisa dianggap belum ada apabila tidak dilakukan konseling.

Istilah konseling dahulu diterjemahkan dengan "penyuluhan". Penerjemahan penyuluhan atas kata konseling ternyata menimbulkan kerancuan dan sering menimbulkan salah persepsi. Dalam peraktik pelayanan bimbingan dan konseling di sekolah termasuk madrasah, konseling dengan arti penyuluhan tidak dilakukan seperti halnya penyuluhan pertanian, hukum, keluarga berencana, dan lain-lain; dimana orang di kumpulkan dalam jumlah yang banyak lalu penyuluh memberikan ceramah. Dalam dunia pendidikan (di sekolah atau madrasah), praktik konseling (yang diterjemahkan penyuluhan) dilakukan dalam suasana hubungan atau komunikasi yang bersifat individual. Istilah konseling yang diadopsi dari bahasa Inggris "counseling" di dalam kamus dikaitkan dengan kata "counsel" memiliki beberapa arti, yaitu nasihat (to abtain counsel), anjuran (to give counsel), dan pembicaraan (to take counsel). Berdasarkan arti di atas, konseling secara etimologis berarti pemberian nasihat, anjuran, dan pembicaraan dengan bertukar pikiran (Suryana \& Suryadi, 2012, pp. 5-6).

Seperti halnya bimbingan, secara terminologi konseling juga di konsepsikan sangat beragam oleh para pakar bimbingan dan konseling. Rumusan tentang konseling yang di konsepsikan secara beragam dalam berbagai literature bimbingan konseling, memiliki makna yang satu sama lain ada kesamaannya. Kesamaan makna dalam konseling setidaknya dapat dilihat dari kata kunci tentang konseling dalam tataran praktik, di mana konseling merupakan; 1) proses pertemuan tatap muka atau hubungan atau relasi timbal balik antara pembimbing (konselor) dan klien (siswa); 2) dalam proses 
pertemuan atau hubungan timbal balik tersebut terjadi dialog atau pembicaraan yang disebut dengan wawancara konseling (Wardati, 2011).

Mortensel dalam (Salahudin, 2010, p. 4) menyatakan bahwa konseling merupakan proses hubungan antara pribadi dimana orang yang satu membantu yang lainnya untuk meningkatkan pemahaman dan kecakapan menentukan masalahnya. Dalam pengertian ini jelas menunjukan bahwa konseling merupakan situasi pertemuan atau hubungan antara pribadi (konselor dan konseli atau klien) dimana konselor membantu konseli agar memperoleh pemahaman dan kecakapan menemukan masalah yang di hadapinya.

Secara implisit, tujuan bimbingan dan konseling sudah bisa diketahui dalam rumusan tentang bimbingan dan konseling seperti yang telah dikemukakan di atas. Individu atau siswa yang dibimbing, merupakan individu yang sedang dalam proses perkembangan. Oleh sebab itu, merujuk pada perkembangan individu yang dibimbing, maka tujuan bimbingan dan konseling adalah agar tercapai perkembangan yang optimal pada individu yang dibimbing. Dengan perkataan lain agar individu (siswa) dapat mengembangkan dirinya secara optimal sesuai dengan potensi dan kapasitasnya dan agar individu dapat berkembang sesuai lingkungannya.

Optimalisasi percakapan tujuan bimbingan dan konseling pada setiap individu tentu berbeda sesuai tingkatan perkembangannya. Apabila yang dibimbing adalah murid Sekolah Dasar (SD/MI), di mana mereka sedang dalam proses perkembangan dari usia SD/MI ke usia SMP/MTs atau usia anak-anak ke usia remaja, tentu optimalisasi pencapaian tingkat perkembangannya sesuai dengan usia Sekolah Dasar.

Individu yang sedang dalam proses perkembangan apa lagi ia adalah seorang siswa, tentu banyak masalah yang dihadapinya baik masalah pribadi, sosial, maupun akademik dan masalah-masalah lainnya. Kenyataan bahwa tidak semua individu (siswa) mampu melihat dan mampu menyelesaiakan sendiri masalah yang dihadapinya serta tidak mampu menyesuaikan diri secara afektif terhadap lingkungannya. Bimbingan dan konseling berkenaan dengan perilaku oleh sebab itu tujuan bimbingan dan konseling adalah dalam rangk; 1) membantu mengembangkan kualitas kepribadian individu yang dibimbing atau dikonseling; 2) membantu mengembangkan kualitas kesehatan mental klien; 3) membantu mengembangkan prilaku-prilaku yang lebih efektif pada diri individu dan lingkungan; 4) membantu klien menanggulangi problem hidup dan lingkungannya secara mandiri (Azzel, 2011, p. 5).

Uman Suherman menyatakan bahwa dasar pemikiran penyelengaraan bimbingan dan konseling di sekolah/madrasah, bukan semata-mata terletak pada ada atau tidak adanya landasan hukum (perundang-undangan) atau 
ketentuan dari atas, namun yang lebih penting adalah menyangkut upaya mempasilitasi peserta didik, yang selanjutnya disebut konseli, agar mampu mengembangkan potensi dirinya atau mencapai tugas-tugas perkembangannya (menyangkut aspek fisik, emosi, intelektual, sosial, dan moral-spiritual) (Suherman, 2011).

Konseli merupakan seorang individu yang sedang berada dalam proses berkembang atau menjadi (on becoming), yaitu berkembangnya ke arah kematangan atau mandiri. Untuk mencapai kematangan tersebut, konseli memerlukan bimbingan karena meraka belum memiliki pemahaman atau wawasan tentang diri dan lingkungannya, juga pengalaman dalam menentukan arah kehidupannya. Di samping itu, terdapat suatu keniscayaan bahwa proses perkembangan konseli tidak selalu berlangsung secara mulus, atau bebas dari masalah. Dengan kata lain, proses perkembangan itu tidak selalu berjalan dalam alur linier, lurus, atau searah dengan potensi, harapan, dan nilai-nilai yang dianut (Milfayetty, 2017, p. 212).

Perkembangan konseli tidak terlepas dari pengaruh lingkungan, baik fisik, psikis maupun sosial. Sifat yang melekat pada lingkungan adalah perubahan. Perubahan yang terjadi dalam lingkungan dapat memengaruhi gaya hidup (life style) warga masyarakat. Apabila perubahan yang terjadi itu sulit diprediksi atau di luar jangkauan kemampuan, terjadilah kesenjangan perkembangan prilaku konseli, seperti terjadinya stagnasi perkembangan, masalah-masalah pribadi, atau penyimpangan prilaku. Perubahan lingkungan yang diduga memengaruhi gaya hidup dan kesenjangan perkembangan tersebut, di antaranya pertumbuhan jumlah penduduk yang cepat, pertumbubahan kota-kota, kesenjangan tingkat sosial ekonomi masyarakat, revolusi informasi, pergeseran fungsi atau stuktur keluarga, dan perubahan stuktur masyarakat dari agraris ke industri.

Dengan demikian, pendidikan yang bermutu, efektif, atau ideal adalah pendidikan yang mengintegrasikan tiga bidang kegiatan utamanya secara sinergi, yaitu bidang administrasi dan kepemimpinan, bidang instuksional atau kurikuler, dan bidang bimbingan konseling. Perdidikan yang hanya melaksanakan bidang administrasi dan instruksional, dengan mengabaikan bidang bimbingan dan konseling, hanya akan menghasilakan konseli yang pintar dan terampil dalam aspek akademik, tetapi kurang memiliki kemampuan atau kematangan dalam aspek kepribadian.

Pada saat ini telah terjadi perubahan paradigma pendekatan bimbingan konseling, yaitu dari pendekatan yang berorientasi tradisonal, remedial, klinis, dan terpusat pada konselor, kepada pendekatan yang berorientasi perkembangan dan preventif, pendekatan bimbingan dan konseling perkembangan (developmental guidance and counseling), atau bimbingan 
konseling komprehensif (comprehensive guidance and counseling). Pelayanan bimbingan dan konseling komprehensif didasarkan pada upaya pencapaian tugas perkembangan, pengembangan potensi, dan pengentasan masalahmasalah konseli. Tugas-tugas perkembangan dirumuskan sebagai standar kompetensi yang harus dicapai konseli sehingga pendekatan ini disebut juga bimbingan dan konseling berbasi standar (standar based guidance and counseling). Standar dimaksud adalah standar kompetensi kemandirian (Milfayetty, 2017, p. 214).

Dalam pelaksanaannya, pendekatan ini menekankan kaloborasi antara konselor dan para personal sekolah/madrasah lainnya (pimpinan sekolah, madrasah, guru-guru dan staf administrasi), orang tua konseli dan pihak-pihak terkait lainnya. Pendekatan ini berintegrasi dengan proses pendidikan di sekolah/madrasah secara keseluruhan dalam upaya membantu para konseli agar mengembangkan atau wujudkan potensi dirinya secara penuh, baik menyangkut aspek pribadi, sosial, belajar maupun karir (Salahudin, 2010, pp. 24-26).

Kehadiran guru bimbingan konseling di sekolah di pandang sangat penting seiring dengan perubahan cara pandang masyarakat pendidikan terhadap eksistensi seorang guru. Bila dahulu seorang guru mempunyai peran penting dan menjadi pusat dalam proses belajar mengajar di kelas, kini guru berperan sebagai pendamping yang menemani siswa belajar untuk mencapai kecerdasan dan kedewasaan. Bila dahulu seorang guru selalu menjadi objek, kini siswa pun diberi kesempatan untuk aktif dalam proses belajar mengajar.

Di samping itu kehadiran guru bimbingan dan konseling dipandang penting karena adanya fakta yang tidak bisa dihindari, yaitu perbedaan individu. Setiap siswa sudah tentu mempunyai kepribadian dan cara berpikir yang berbeda. Di sisi lain, kegiatan belajar mengajar di sekolah pada umumnya diselenggarakan secara klasikal. Cara belajar demikian tentu ada kekurangan, yaitu kurang memperhatikan perbedaan siswa dalam kemampuannya mengikuti pelajaran. Disinilah sesungguhnya pentingnya guru bimbingan dan konseling berperan dalam memberikan bantuan kepada siswa yang mempunyai perbedaan tersebut (Azzel, 2011, pp. 54-55).

\section{Metode Penelitian}

Penelitian ini meneliti mengenai unjuk kerja guru bimbingan konseling dalam mengatasi masalah belajar siswa, hal tersebut merupakan masalah kompleks yang dinamis dan penuh makna sehingga tidak mungkin data pada situasi sosial tersebut dijaring dengan metode penelitian kuantitatif. Selain itu masalah yang diteliti juga merupakan masalah yang bersifat holistik, dimana masalah 
tersebut tidak dapat dipisah-pisahkan akan tetapi harus mencangkup keseluruhan situasi sosial yang ada, sehingga penulis menggunakan metode penelitian kualitatif. Sugiyono mengungkapkan "bahwa penelitian kualitatif berusaha menggambarkan suatu gejala sosial” (Sugiyono, 2009b, p. 1). Lebih lanjut, Sugiyono mengemukakan bahwa dengan "menggunakan metode kualitatif, maka data yang didapat akan lebih lengkap, lebih mendalam, kredibel, dan bermakna sehingga tujuan penelitian dapat dicapai (Sugiyono, 2009a, p. 205).

Dalam penelitian ini, peneliti menggunakan pendekatan deskriptif kualitatif, yaitu sebuah prosedur penelitian berdasarkan data deskriftif yaitu berupa lisan atau kata tertulis dari subjek penelitian atau informan yang telah diamati dan memiliki karaktristik bahwa data yang diberikan merupakan data asli menurut situasi dan kondisi yang tidak dapat di manipulasi serta menggunakan cara sistematis dan dapat dipertanggung jawabkan kebenarannya. Penelitian kualitatif adalah suatu pendekatan penelitian yang mengungkat situasi sosial tertentu dengan mendeskripsikan kenyataan secara nyata, dideskripsikan melalui kata-kata berdasarkan teknik pengumpulan data dan analisa data yang relevan diperoleh dari situasi yang dialami (Satori \& Komariah, 2011, p. 25).

Subjek Penelitian atau responden adalah orang yang diminta untuk memberikan keterangan tentang suatu fakta atau pendapat. Sebagaimana dijelaskan oleh Arikunto subjek penelitian adalah subjek yang dituju untuk diteliti oleh peneliti. Jadi, subjek peneliti merupakan sumber informasi yang digali untuk mengungkap fakta-fakta di lapangan (Arikunto, 2006, p. 145). Subjek penelitian yang akan di ambil dalam penelitian ini adalah murid kelas VI MIS Handapherang yang bermasalah dalam suatu pembelajaran di kelas dan Guru bimbingan konseling dalam menyelesaikan permasalahan anak tersebut.

Menurut sugiyono "teknik pengumpulan data merupakan langkah yang paling strategis dalam penelitian, karena tujuan utama dari penelitian mendapatkan data". Proses pengumpulan data terhadap suatu penelitian yang penulis lakukan, harus memiliki cara dan teknik untuk mendapatkan data atau informasi yang baik dan akurat dari setiap apa yang diteliti, sehingga kebenaran dan informasi data yang diperoleh dapat dipertanggung jawabkan. Dalam penelitian ini penulis menggunakan teknik pengumpulan data dengan cara observasi dan wawancara (Sugiyono, 2009a, p. 62).

Observasi merupakan suatu penelitian yang dijalankan secara sistematis dan sengaja diadakan dengan menggunakan alat indra (terutama mata) atas kejadian-kejadian yang langsung dapat di tangkap pada waktu kejadian itu berlangsung. Agar observasi dapat berhasil dengan baik, salah satu hal yang 
harus dipenuhi ialah alat indra harus dipergunakan dengan sebaik-baiknya (Walgito, 2010, p. 61).

Wawancara (interview) secara umum adalah suatu percakapan antara dua atau lebih orang yang dilakukan oleh pewawancara dan narasumber. Ada juga yang mengatakan bahwa definisi wawancara adalah suatu bentuk komunikasi lisan yang dilakukan secara terstruktur oleh dua orang atau lebih, baik secara langsung maupun jarak jauh. Menurut Lexy J. Moleong pengertian wawancara adalah suatu percakapan dengan tujuan-tujuan tertentu. Pada metode ini peneliti dan responden berhadapan langsung (face to face) untuk mendapatkan informasi secara lisan dengan tujuan mendapatkan data yang dapat menjelaskan permasalahan penelitian (Moleong, 2010). Instrument pengumpulan data merupakan langkah yang paling utama dalam penelitian, karena tujuan utama dari peneliti adalah mendapatkan data. Tanpa mengetahui teknik pengumpulan data, maka peneliti tidak akan mendapatkan data yang memenuhi standar data yang di tetapkan (Sugiyono, 2009b, p. 308)

\section{Hasil Penelitian dan Pembahasan}

Dari hasil penelitian dan wawancara dengan guru kelas di sekolah MIS Handapherang peneliti menemukan masalah belajar pada anak kelas VI, masalah belajarnya adalah siswa belum lancar dalam hal menulis dan membaca. Siswa tersebut bernama Nunung, dia dilahirkan sebagai anak pertama dari satu adik. Latar belakang pendidikan keluarga Nunung semuanya lulusan sekolah dasar (SD). Pekerjaan ayah dan ibu Nunung buruh dan pedangan keliling. Siswa tersebut mengalami masalah belajar yaitu kekurangan dari segi kognitif dan memiliki kelebihan dari segi afektif, diantarnya dari segi kognitif siswa tersebut memiliki kekurangan tidak bisa membaca dan menulis, IQ dibawah rata-rata.

Padahal tingkat intelijensi IQ seseorang sangat memengaruhi kemampuan kognitifnya. Hubungan antara kecerdasan dengan nilai kemampuan kognitif berkorelasi signifikan dan positif. Semakin tinggi nilai kecerdasan seseorang, semakin tinggi pula tingkat kemampuan kognitifnya (Fatimah, 2006, p. 31). Meskipun siswa tersebut memiliki kekurangan dari segi kognitif, akan tetapi perkembangan afektif seorang memiliki kelebihan dari segi sosialnya, diantaranya: sopan terhadap guru, ramah, aktif bertanya di kelas. Prilaku seorang nunung ini sangatlah baik karena prilaku tersebut membawa pengaruh dan manfaat tertentu bagi siswa.

Proses perkembangan sosial selalu berkaitan dengan proses belajar. Kualitas hasil perkembangan sosial siswa sangatlah bergantung pada kualitas proses belajar (khususnya belajar sosial) siswa tersebut, baik di lingkungan 
sekolah dan keluarga maupun di lingkungan yang lebih luas. Ini bermakna bahwa proses belajar itu amat menentukan kemampuan siswa dalam bersikap dan berperilaku sosial yang selaras dengan norma moral agama, moral tradisi, moral hukum, dan norma moral lainnya yang berlaku dalam masyarakat siswa yang bersangkutan (Syah, 2005, p. 76).

Pihak sekolah awalnya menyarankan Nunung masuk sekolah SLB, akan tetapi orang tuanya tidak menginginkan anaknya masuk sekolah SLB, karena orang tua beranggapan bahwa anak saya normal seperti anak yang lainnya. Nunung sempat pernah tidak naik kelas pada waktu kelas 1 dan kelas 2 . Masalah yang terjadi pada Nunung ini sangat serius karena seharusnya anak kelas VI harus bisa membaca dan menulis, sehingga guru kelas harus menyelesaikannya dengan guru Bimbingan Konseling (BK). Ada dua faktor yang mempengaruhi Nunung mengalami masalah belajar yaitu dari faktor internal dan eksternal. Faktor internal adalah faktor permasalahan yang timbul dari dalam diri siswa, dari hasil penelitian dan wawancara dengan guru kelas terdapat satu permasalahan yang mengakibatkan siswa mengalami masalah belajar.

Di antara masalah tersebut kurangnya motivasi belajar. Motivasi merupakan bagian terpenting dalam kegiatan belajar, tanpa adanya motivasi yang tinggi siswa akan mengalami kesulitan dalam pembelajaran, tidak punya tujuan yang jelas. Motivasi yang tinggi berasal dari perkataan orang tua kemudian motivasi dari dalam diri sendiri. Faktor masalah yang terjadi pada murid kelas VI MIS Handapherang yaitu kurangnya motivasi dalam diri sendiri, contoh permasalahan yang terjadi pada murid ketika tidak memiliki motivasi semangat untuk belajar; 1) sering tidak mengerjakan tugas sekolah; 2) berpakaian tidak rapih; 3) buku sekolah tidak pernah rapih; 4) guru menyuruh mengerjakan tugas di kelas tidak pernah di kerjakan.

Maka dapat di simpulkan ketika siswa tidak memiliki motivasi belajar, siswa akan acuh terhadap pembelajaran, penampilan dan sikap. Motivasi merupakan sebuah dorongan untuk menggerakan dan mengarahakan perilaku diri sendiri. Dalam motivasi terkandung adanya keinginan yang mengakktifkan dan menggerakan diri sendiri. Motivasi juga sangat berpengaruh besar terhadapat cara belajar, ketika siswa memiliki motivasi yang tinggi mereka akan belajar lebih semangat, tekun serta memiliki konsentrasi yang kuat dalam proses pembelajaran.

Di satu sisi, faktor eksternal adalah faktor permasalahan yang timbul dari luar diri siswa. Faktor ini di pengaruhi oleh keluarga, lingkungan sosial, masyarakat, dari hasil penelitian dan wawancara dengan guru kelas, peneliti menemukan satu permasalahan yang membuat siswa mengalami masalah belajar yaitu faktor keluarga. Keluarga adalah jantung dari pendidikan anak. 
Pendidikan yang pertama ada dalam lingkungan keluarga, pendidikan yang ke dua ada di sekolah dan yang ke tiga ada di masyarakat. Kebanyakan orang tua di zaman sekarang sibuk dengan urusan pekerjaanya masing-masing sehingga anak kurang kasih sayang dan motivasi belajar. Orang tua berkewajiban memberikan dorongan dan motivasi belajar kepada anak, didikan orang tua yang kurang baik akan berpengaruh tidak baik terhadap kondisi anak dalam belajar. Seperti yang terjadi pada Nunung siswa kelas VI MIS Handapherang, masalah yang tejadi pada Nunung ini yaitu dari faktor pendidikan di keluarga antara lain; 1) kurangnya perhatian kepada anak; 2) orang tua tidak pernah menyuruh anak mengerjakan PR sekolah; 3) kurangnya motivasi belajar kepad anak; 4) kurangnya kasih sayang dari orang tua; 5) sering tidak masuk kelas karena di suruh oleh orang tuanya untuk menjada adiknya yang masih kecil sedangkan orang tuanya sibuk berjualan.

Dalam dunia pendidikan yang terjadi seperti itu sangatlah tidak baik, seharusnya anak fokus untuk belajar menggapai sebuah harapan dan cita-cita. Orang tua sangatlah berperan penting dalam dunia pendidikan anak, jangan sampai anak yang menjadi korban dalam prekonomian yang ada dalam keluarga.

Di sekolah MIS Handapherang layanan bimbingan konseling dilakukan untuk mengatasi kesulitan belajar pada siswa melalui bimbingan individual maupun kelompok. Sebelum melakasanakan bimbingan konseling, guru kelas terlebih dahulu mengindentifikasikan kesulitan yang dihadapi siswanya. Kemudian guru mengumpulkan data siswa yang mengalami kesulitan dalam belajar untuk dianalisis apa penyebab yang mengakibatkan siswanya mengalami masalah ketika dalam prores pembelajaran berlangsung. Setelah guru mengetahui penyebab kesulitan belajar yang di alami siswanya guru segera menentukan jenis kesulitan belajar dan cara mengatasi kesulitan belajar tersebut. Kemudian guru kelas berdiskusi dengan guru bimbingan konseling bagaimana cara mengatasi anak yang mengalami masalah belajar. Dalam upaya mengatasi masalah belajar siswa kelas VI sebelum di tangani oleh guru bimbingan konseling guru kelas selalu memberikan motivasi belajar untuk lebih semangat dan bersungguh-sungguh dalam mencari ilmu, selalu di perhatikan, di bimbing dalam pembelajaran dan selalu diberi arahan pada saat proses pembelajaran berlangsung di dalam kelas.

\section{Kesimpulan}

Pendidikan orang tua sangatlah penting bagi anak, pendidikan orang tua merupakan jantung dari pendidikan anak. Pendidikan yang pertama ada pada pendidikan dari orang tua, jika anak di didik dari kecil dengan baik oleh orang 
tuanya maka saat anak beranjak ke dunia pendidikan selanjutnya di sekolah, anak tidak akan mengalami masalah belajar seperti yang terjadi pada anak kelas VI MIS Hadapherang. Berdasarkan hasil penelitian dari rumusan masalah yang diajukan tentang mengatasi masalah belajar siswa melalui bimbingan guru konseling, maka dapat diperoleh kesimpulan sebagai berikut. Pertama, faktor masalah belajar yang terjadi pada siswa kelas VI MIS Handapherang ini ada dua faktor, faktor internal dan eksternal. Faktor internal ini berasal dari diri siswa sendiri, kurangnya motivasi pada diri sendiri sangatllah berpengaruh besar dalam proses pembelajaran. Faktor eksternal berasal dari luar diri siswa, faktor ini di pengaruhi dari faktor pendidikan di lingkungan keluarga. Di zaman sekarang orang tua beranggapan bahwa pendidikan yang pertamam ada di lingkungan sekolah, akan tetepai pendidikan pertama yang sebenarnya ada di lingkungan keluarga. Kedua, upaya yang dilakukan guru kelas dan guru bimbingan konseling di sekolah pada salah seorang siswa kelas VI yang mengalami masalah belajar yaitu dengan cara memaksimalkan indra pendengarannya, dibimbing, diarahkan, diperhatiakan dalam proses pembelajaran. Indra pendengaran siswa yang bermasalah sangatlah baik, akan tetapi dari segi menulis dan membaca siswa mengalami masalah. Ketiga, Tahapan guru bimbingan konseling di sekolah MIS Handapherang dalam mengatasi masalah belajar siswa cukup baik, dari mulai menentukan masalah sampai dengan penyelesaian masalah yang terjadi pada siswa kelas VI MIS Handapherang.

\section{DAFTAR PUSTAKA}

Ali, M. (2000). Guru Dalam Proses Belajar Mengajar. Bandung: Sinar Baru Algesindo.

Andi, H. (2002). Bimbingan dan Konseling dalam Islam. Jakarta: Ciputat Press. Arikunto, S. (2006). Prosedur Penelitian Suatu Pendekatan Praktik. Jakarta: Rineka Cipta.

Azzel, A. M. (2011). Bimbingan dan Konseling di Sekolah. Yogyakarta: Ar-Ruzz Media.

Dahlan, Z. (2017). Peningkatan Kualitas Kompetensi Guru BK Sebagai Konselor di Sekolah dalam Menghadapi Tantangan Global. Al-Irsyad, $8(1), 8-17$.

Dimyati, \& Mudjiono. (2013). Belajar dan Pembelajaran. Jakarta: Rineka Cipta.

Djamarah, S. B. (2008). Psikologi Belajar. Jakarta: Rineka Cipta.

Fatimah, E. (2006). Psikologi perkembangan (perkembangan peserta didik). Bandung: CV. Pustaka Setia. 
Milfayetty, S. (2017). The Spirit of Goodness Sebagai Landasan Pemikiran dan Perilaku Konselor / Guru BK dalam Pelayanan Konseling. Seminar \& Workshop Nasional Bimbingan dan Konseling: Indonesian Counselor Association| Ikatan Konselor Indonesia (IKI), 3, 211-214.

Moleong, J. L. (2010). Metodologi Penelitian Kualitatif. Bandung: PT. Remaja Rosdakarya.

Prayitno, \& Amti, E. (2004). Dasar-Dasar Bimbingan dan Konseling. Jakarta: PT. Asdi Mahasatya.

Salahudin, A. (2010). Bimbingan dan Konseling. Bandung: CV. Pustaka Setia.

Satori, D., \& Komariah, A. (2011). Metodologi Penelitian Kialitatif. Bandung: Alfabeta.

Slameto. (2015). Belajar dan Faktor-Faktor Yang Mempengaruhi. Jakarta: PT. Rineka Cipta.

Sugiyono. (2009a). Metode Penelitian Kuantitatif, Kualitatif dan RéD. Bandung: Alfabeta.

Sugiyono. (2009b). Metodologi Penelitian. Jakarta: RajaGrafindo Persada.

Suherman, U. (2011). Pembangun Karakter dan Budaya Bangsa Melalui Bimbingan Komprehensif Berbasis Nilai Alquran (Tinjauan Filosofis tentang Hakikat dan Peran Manusia). Bandung: UPI Bandung.

Suryana, A., \& Suryadi. (2012). Modul Bimbingan dan Konseling (Cet. 2). Jakarta: Direktorat Jenderal Pendidikan IslamKementerian Agama R. Syah, M. (2002). Psikologi Pendidikan. Bandung: PT. Remaja Rosdakarya.

Syah, M. (2005). Psikologi Pendidikan dengan Pendekatan Baru. Bandung: PT. Remaja Rosdakarya.

Tohirin. (2007). Bimbingan dan Konseling di Sekolah dan Madrasah (Berbasis Integrasi). Jakarta: PT. Raja Grafindo Persada.

Walgito, B. (2010). Bimbingan dan Konseling (Studi \& Karier). Yogyakarta: CV. Andi Offset.

Wardati. (2011). Implementasi Bimbingan Dan Konseling Di Sekolah. Jakarta: Prestasi Pustakarya.

Winkel, W. S., \& Hastuti, M. M. S. (2013). Bimbingan Konseling di Instusi Pendidikan. Jakarta: Grasindo. 